\title{
Spilling the beans on the pharmaceutical industry
}

Side Effects: A Prosecutor, a

Whistleblower, and a Bestselling

Antidepressant on Trial

Alison Bass

Algonquin Books of Chapel Hill; 2008

260 pp \$24.95 ISBN978 1-56512-553-7

Our Daily Meds: How the Pharmaceutical Companies Transformed Themselves into slick Marketing Machines and Hooked the Nation on Prescription Drugs

Melody Petersen

Sarah Crichton Books, Farrar, Straus and Giroux; 2008

414 pp \$26.00 ISBN 978-0-374-22827-9

$\mathrm{T}$ he past 4 years have witnessed a wave of books condemning the pharmaceutical industry for unethical practices, but in 2008, Pharma began to turn the corner, transformed by clinical trial registries, bans on ghostwritten papers and (south of the border, at least) transparency regarding companies' submissions to regulators. The transformation is in many ways a credit to whistleblowers and to those who acted on their evidence. Two new books from US journalists - Side Effects by former Boston Globe reporter, Alison Bass and Our Daily Meds by Melody Petersen, who covered Pharma for the New York Times - expand our understanding of this tarnished industry by introducing us to a few of the individuals who found themselves battling against it from the inside and chose to come forward.

Side Effects lays out the compelling drama of how New York's thenattorney general Elliot Spitzer - before his downfall while state governor - charged GlaxoSmithKline with fraud for deceiving doctors about its blockbuster antidepressant, paroxetine (Paxil). Though the case is complicated, the book draws readers along in what could almost be a screenplay for a North American version of the Constant Gardener, the award-winning 2005 film about the pharmaceutical in-

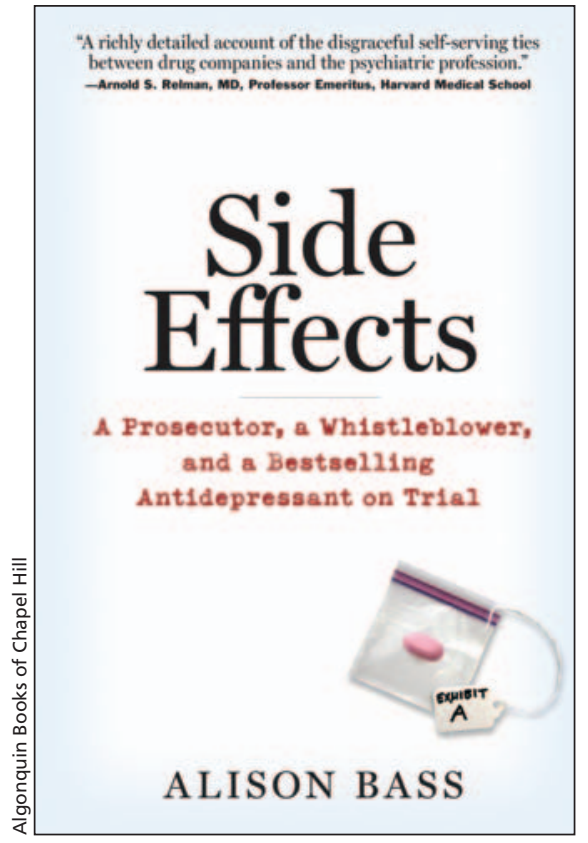 \\ dustry's bad behaviour in Africa. Here the heroine is Rose Firestein, a nearly blind, diabetic woman in her 50s who toiled behind the headlines as an assis- tant attorney general, digging for evi- dence that would prove the company's bad behaviour was criminal. Through scanning the literature and meeting with a whistle-blower, she discovered the hidden studies showing that paroxe- tine doesn't work against depression in children and adolescents and jumped on them. "I think we can argue that by not fully disclosing all of its research \\ At this point, $C M A J$ gets a walk-on part in the book. In 2004, CMAJ re- vealed a confidential memo in its news pages that proved the makers of parox- etine "knew they were holding back in- formation and that what they were do- ing was wrong," as a lawyer in the New York attorney general's office put it later. 'The CMAJ's news story pro- vided the attorney general's office with the requisite smoking gun in a case that turned out to have broad implications. In a settlement, Glaxo agreed to post its clinical trial results, jump-starting the international movement to register all clinical trials. \\ Writing with a novelist's touch and honing her material for its underside, Bass has produced a gripping who- dunit replete with dead bodies, hidden documents, public monies spent on nonexistent studies and even a sham court verdict. \\ Our Daily Meds, a treatise on the overuse and misuse of brand-name medications, also has corpses, but it's closer to advocacy journalism than nar- rative nonfiction. For Petersen, the pharmaceutical companies cause "far too much needless harm" through their "profiteering," and she refers so often to the "medicine merchants" and "med- icine marketers" with their "hoards of cash" and "cash-filled coffers" that, at times, Our Daily Meds becomes an un- enlightening, one-sided screed. But}

Bass has produced a gripping whodunit replete with dead bodies, hidden documents and a sham court verdict.

results, Glaxo is guilty of fraud under the New York statute!" she told a colleague. But the attorney general's office had never sued a drug company on those grounds and, initially, none of her superiors thought it was possible. Firestein had to convince the team and Bass lets us watch her do it. what lifts it up, and will stay with you, are the individual characters she depicts and the dramas they're caught in. Iowa is Petersen's home state and she went there to be a fly-on-the-wall as drug company sales reps subtly suggested that consumers swallow new pills. At the medical centre in Storm Lake, 
Iowa, population 20 000, she lunched with a group of women who were being encouraged to worry about sleepless nights. One said she thought her antidepressant was keeping her awake, but the luncheon speaker, a rep for Sanofi-Aventis, makers of the bestselling sleeping pill, zolpidem (Ambien), wasn't discussing drug side effects; she was describing insomnia, a condition she said could result in forgetfulness, moodiness, heart disease, obesity, "psychotic issues" and car crashes. "I don't mean to scare you," the rep told the assembled women, but of course, she did. Her job, it seems, was to leave the women, half of whom were seniors, terrified of insomnia and besieging their doctors for zolpidem, described in kits left in the lunchroom as the country's “\#1 prescribed sleep aid." What the women weren't told is that for many patients, especially the elderly, the risks of sleeping pills outweigh their benefits. Zolpidem's side effects - daytime sleepiness, amnesia, and dizziness - can lead to falls and fractures and it has such high potential for addiction that its label warns doctors not to prescribe it for more than 10 days.

Our Daily Meds demonstrates that many of the deaths and injuries that result from prescription drugs aren't accidents; they're the direct result of a multitiered system of inducements that drug companies hurl at doctors, consumers, magazine publishers, hospitals, pharmacies, and elected officials, to name a few. Petersen gives concrete evidence of this via the story of David Franklin, a scientist who went to work for Parke Davis in 1996 as a sales rep touting the

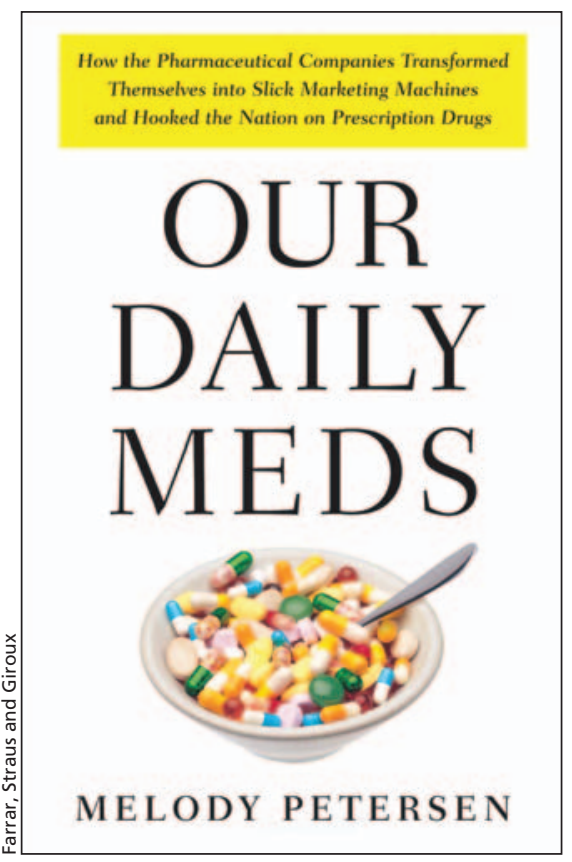

benefits of the antiseizure medication, gabapentin (Neurontin) and found himself morally repulsed by his job. A group of Parke Davis executives calling themselves the New Product Committee instructed Franklin and his fellow reps to promote gabapentin for conditions where there's minimal evidence that it works, then told them to be careful to communicate solely through the corporate voice mail program since anything in writing could be audited. Instead,
Franklin taped the voice mails and filed suit under the United States false claims act, a unique mechanism that can provide an incentive to whistle-blowers who discover their employers are ripping off the government. The company eventually paid the government nearly a half-billion dollars and, as the whistleblower in the case, Franklin's share was nearly \$30 million. Petersen, angry that none of those behind the gabapentin scheme were sanctioned, argues for a reform plan that would throw a few pharma executives in jail, but leaves readers wondering about Franklin. How did he fare when he faced his former superiors in court? Why was he the only employee who was driven to complain publicly about the company's practices? And, most important, why did he blow the whistle instead of just walking away?

The value of both these books is that they underscore how crucial such a decision can be. The change that's coming to Pharma has been brought about by the converging efforts of several Rose Firesteins and David Franklins, watching, listening and spilling the beans.

\section{Miriam Shuchman MD \\ Psychiatrist \\ Toronto, Ont.}

\section{REFERENCE}

1. Kondro W, Sibbald, B. Drug company experts advised staff to withhold data about SSRI use in children. CMAJ 2004;170:783

\section{Holiday Reading Acknowledgements}

Our call for submissions to the Holiday Reading section - a literary deviation from our usual Holiday Review - drew an unprecedented number of submissions, resulting in some extremely difficult judging decisions. Thank you to our esteemed panel of reading enthusiasts: Erin Driscoll, Jesse Craig, Kate Schissler, Kelly Clarke, Patricia Lightfoot and Wayne Kondro. Thanks also to our designer Carole Lalonde. And a very special thank you to

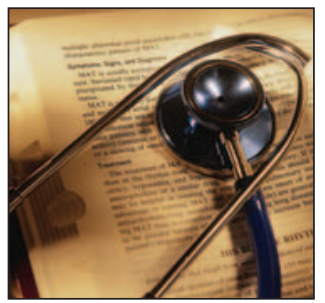
everyone who submitted a manuscript.

Wishing you many hours of enjoyable reading over the holidays,

Barbara Sibbald

Deputy Editor, News and Humanities 